\title{
Five new species of Hemibrycon (Characiformes: Characidae) from the Río Magdalena basin, Colombia
}

\author{
César Román-Valencia \& Dahiana K. Arcila-Mesa \\ Laboratorio de Ictiología, Universidad del Quindío, A. A. 2639, Armenia, Colombia; ceroman@uniquindio.edu.co, \\ arciladk@gmail.com
}

Received 30-V-2009. Corrected 06-VII-2009. Accepted 06-VIII-2009.

\begin{abstract}
Five new fish species of the genus Hemibrycon are described from the Río Magdalena basin, Colombia, using morphometric, meristic and osteological characters. Hemibrycon paez $(n=40)$ differs in number of lateral line scales ( 39 to 42 vs. 43 to 54), by the number of scales between lateral line and anal-fin origin ( 6 to 7 vs. 4 to 5 ) and between lateral line and dorsal-fin origin ( 6 to 7 vs. 8); H. quindos ( $\mathrm{n}=66)$ distinguished from its congeners by one autopomorphy: Males with cartilaginous protuberance, rounded on the anal fin ray branched, along all rays (vs. cartilaginous protuberance not present on anal-fin rays in males), by the maxilla without a fold on its anterior end (vs. maxilla with folding only at posterior end), by the number of pored scales in the lateral line ( 35 to 40 vs. 40 to 46 ); H. raqueliae ( $\mathrm{n}=117$ ) distinguished by a widened first tooth on the maxilla with the remaining teeth decreasing sharply in size (vs. first tooth of maxilla slender, remaining teeth gradually diminishing), by the first maxilla tooth pentacuspid and wider than the others (vs. first tooth on maxilla unicuspid or tricuspid and of same size as the others); H. virolinica $(\mathrm{n}=34)$ distinguished by the posterior end of the extrascapular spine surpassing the postemporal (vs. posterior end of extrascapular not exceeding postemporal spine), by having the posterior end of the first proximal pteryigiophores of dorsal fin of the same size as the anterior edge (vs. the posterior end of the first proximal pteryigiophores of dorsal fin more elongated than the anterior edge); and H. yacopiae $(\mathrm{n}=78)$ is distinguished by the following autopomorphic characters: first laterosensorial infraorbitals canal in contact with the posterior end of antorbital (vs. laterosensorial canal not reaching posterior end of antorbital), by the tip of the supraoccipital spine widened (vs. supraoccipital spine acute), by the posterior end of ectopterygoids failing to come in contact with the quadrate bone (vs. in contact); by the posterior edge of palatine more widened than the anterior edge of ectopterygoids (vs. posterior edge of the palatine approximately the same size, except for H. paez). Rev. Biol. Trop. 58 (1): 339-356. Epub 2010 March 01.
\end{abstract}

Key words: Hemibrycon, teleostei, new taxon, neotropical fish.

The genus Hemibrycon consists of fishes that as adults reach between 25 and $120 \mathrm{~mm}$ standard length (SL) (Géry 1962, RománValencia et al. 2006, 2007, 2008, 2009b Román-Valencia \& Arcila-Mesa 2008, ArcilaMesa 2008). They are characterized by the presence of more than four teeth on the maxilla (in adults) (Eigenmann 1927, Román-Valencia 2001). A phylogenetic analysis of Hemibrycon genus determined its monophyly based on four synapomorpies: presence ectopterygoids with widened ventral anterior projection, four to six times wider than posterior part; a red spot present in life on ventral margin of caudal peduncle; a postero-ventral projection on the pterotic and first infraorbitals gradually decreasing in width from posterior tip and located near posterior part of antorbital (ArcilaMesa 2008).

The first revision of the genus Hemibrycon is by Eigenmann (1927) who recognized 14 species distributed in East and Western Bolivia, Peru, Ecuador, Colombia, Panama, Venezuela, Trinidad and Guyana. Géry (1962, 1977) considered that there are from 16-18 species that inhabit the periphery of the Amazon 
and Orinoco Basins. Eschmeyer (2005) list 24 species. Lima et al. (2003) list 19 species, but currently only 21 species are considered valid: $H$. beni, $H$. boquiae, $H$. brevispini, $H$. colombianus, $H$. coxeyi, $H$. cairoense, $H$. dariensis, $H$. divisorensis, $H$. guppyi, $H$. helleri, $H$. huambonicus, $H$. jabonero, $H$. jelskii, $H$. metae, $H$. orcesi, $H$. pautensis, $H$. polyodon, $H$. rafaelense, $H$. surinamensis, $H$. taeniurus and H. tridens (Planquette et al. 1996; RománValencia 2001; 2004; Román-Valencia et al. 2006, 2007; Bertaco et al. 2007; Román-Valencia \& Arcila-Mesa 2008; Arcila-Mesa 2008). Hemibrycon new sp. Río Güejar, Macarena and Hemibrycon new sp. Río Ranchería, Guajira are in process of publication (Román-Valencia et al. 2009b).

We now recognize seven Colombian species of Hemibrycon as valid: $H$. boquiae, $H$. colombianus, $H$. dariensis, $H$. metae, $H$. rafaelense, $H$. brevispini and $H$. cairoense (Román-Valencia 2001, Román-Valencia \& Arcila-Mesa 2008, Román-Valencia \& ArcilaMesa 2009). The purpose of this paper is to describe five new species of Hemibrycon from the Río Magdalena basin, Colombia, as a further contribution to the ongoing revision of the genus.

\section{MATERIAL AND METHODS}

Fishes were captured using a seine and were preserved with $10 \%$ formalin and later stored in $70 \%$ ethanol. Measurements were made with digital calipers to $0.01 \mathrm{~mm}$ precision and are expressed as percentages of standard (SL) and head lengths (HL) (Tables 1-2). Measurements and counts were taken on the left side, except when that side was damaged. Counts and measurements were recorded following the methodology described in Vari \& Siebert (1990). We performed an analysis of variance (ANOVA, where $\mathrm{F}=$ valor, $\mathrm{n}=$ sample and $\mathrm{p}=$ probability) and a Tukey test $(\mathrm{Q})$, to demonstrate significance of meristic data. In order to analyze the dependence of cartilaginous protuberance on anal-fin rays with sex and size at maturity, a logistic regression was performed for Hemibrycon quindos, where the presence or absence of cartilaginous protuberance was the dependent variable, height and sex the independent variables. The software programs Past version 1.75 and Statgraphics version 5.0. (Windows) were used.

Cleared and stained specimens (C\&S) were prepared according to Taylor \& van Dyke (1985). Bone nomenclature follows Weitzman (1962) and Vari (1995). Abbreviations used in figures: ect, ectopterygid; ext, extrascapular; mes, mesopterydoid; met, metapterygoid; post, postemporal; preo, preopercle; qua, quadrate; sph, sphenotic. Institutional abbreviations follow standard ASIH abbreviations listed at http:// www.asih.org/files/codons.pdf, with addition of Instituto de Investigaciones Biológicas "Alexander Von Humboldt", Villa de Leyva, Boyacá, Colombia (IAvH); Laboratorio de Ictiología, Universidad del Quindío, Armenia, Colombia (IUQ); Museo de Zoología, Departamento de Ciencias Biológicas, Escuela Politécnica Nacional de Quito, Ecuador (MEPN); Fundación La Salle de Ciencias NaturalesMuseo de Historia Natural, Caracas, Venezuela (MHNLS). In examined and comparative material the specimens number are in parenthesis.

Comparative material: In addition to the specimens listed below, see also those listed in Román-Valencia (2001, 2004), Román-Valencia et al. (2006, 2007), RománValencia \& Arcila-Mesa (2008, 2009), RománValencia et al. (2009). Hemibrycon boquiae: IUQ 534, (64); Colombia, Quinchía; Upper Cauca, Los Ramírez creek, Italia creek, El Cairo, at Quinchía-El Cairo road. IUQ 537, (2) (C\&S); Colombia, Risaralda; Quinchía; Los Ramírez creek, Italia creek, El Cairo, Quinchía-Cairo road. IUQ 536, (4) (C\&S); Colombia, Quinchía; Opirama, Río Opirama, Talabám creek, $\left(75^{\circ} 45^{\prime} 08^{\prime}\right.$ W; 5 $5^{\circ} 17^{\prime} 47^{\prime}$ " N), 1172m.a.s.l. IUQ 871, (15); Colombia, Quindío; Boquia creek, Río Quindío. IUQ 301a, (3) (C\&S); Colombia, Quindío; Upper Cauca, Boquia creek, Río Quindío, BoquiaSalento road. IUQ 544, (2) (C\&S); Colombia, Quindío; Salento, La Nubia, Upper Cauca, 


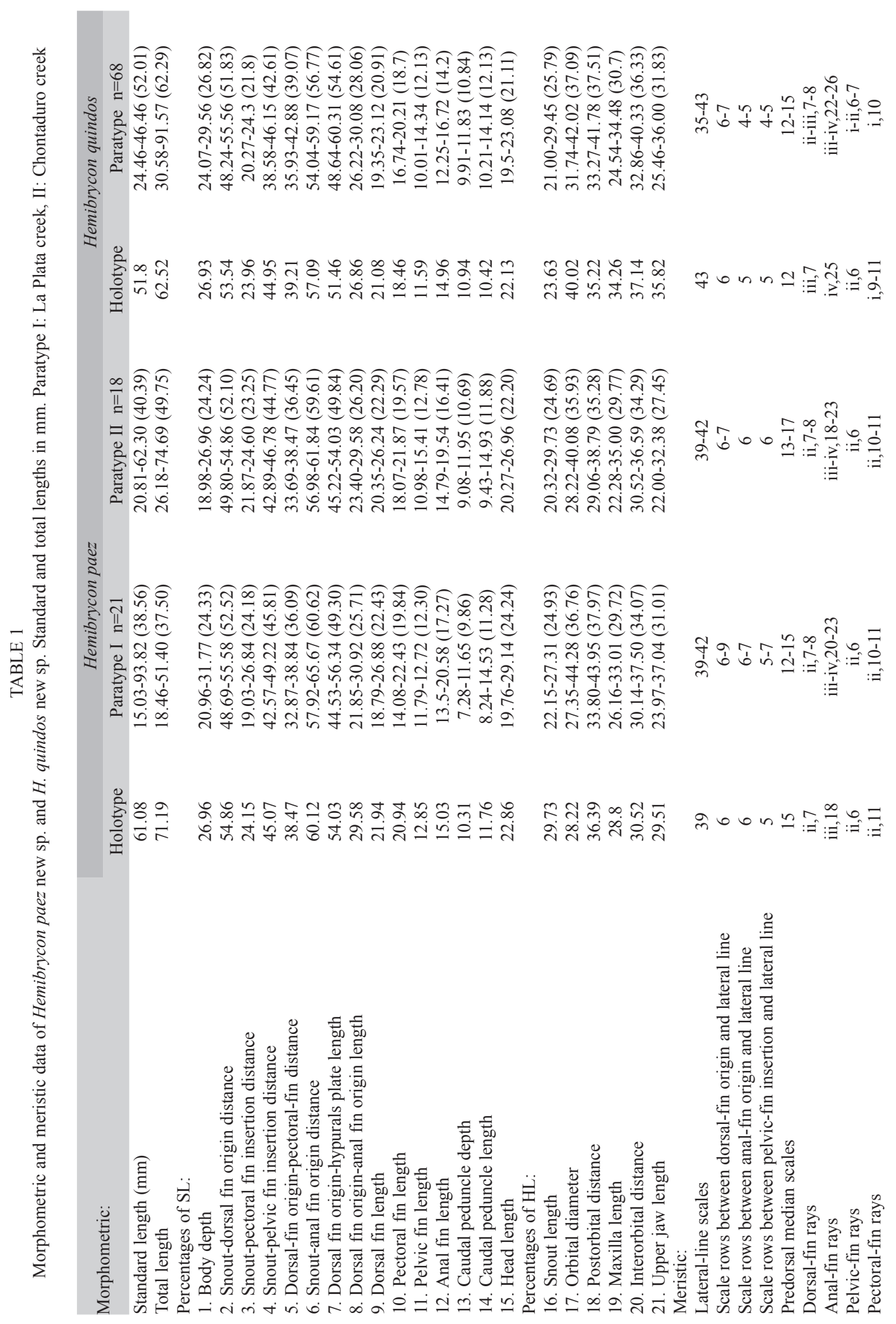







Río Quindío, Las Águilas creek, San JuanLa Nubia road, Río Quindío (75³7'17' W; 4³6’04" N), 1601m.a.s.l. IUQ 547, (2) (C\&S); Colombia, Quindío; Salento, Upper Cauca, El Agrado-Boquia road, Upper Cauca, Río Quindío, La Víbora creek. IUQ 550, (2) (C\&S); Colombia, Quindío; El Agrado, Upper Cauca, Río Quindío, Doña Juana creek 500m before from La Víbora creek, San Juan-Boquia road (753' 54" W; 4³7'39" N), 1714m.a.s.l. IUQ 551, (2) (C\&S); Colombia, Quindío; Salento, El Agrado to Boquia road, Upper Cauca, Río Quindío, Villa Paola creek $\left(75^{\circ} 35^{\prime} 59^{\prime \prime} \mathrm{W}\right.$; 4³7'38" N). IUQ 880, (70); Colombia, Caldas; Río Honda, Aranzazu road. IUQ 857, (19); Colombia, Caldas; Middle Cauca, Río Chamberri, La India, Salamina, Caldas (75'30'10', W; 5'24'55" N). H. colombianus: ICNMNH 753, 4; Colombia, Santander; Río Nevado, Capita Negro. ICNMNH 755, (1) (C\&S); Colombia, Santander; Río Nevado, Capita Negro. IAvH 3130, (28); Colombia, Santander, Río Moniquira and Suárez. H. dariensis: IUQ 849, (26); Colombia, Río Zungo, road, system Río León. IUQ 888, (6); Colombia, Antioquia; Río Piedras Blancas, system Río Sucio, km. 39 Dadeiba-Mutata road, Mutata. IUQ 929, (3); Colombia, Santa Marta; Honduras creek, road to Mutaizhi. IUQ 852, (2) (C\&S); Colombia, Uraba, Villa Ortega. IUQ 1280, (32); Colombia; Río Ranchería. IUQ 1281(17); Colombia; sea Caribe, Guajira, Río Ranchería. H. guppyi: USNM 290406, (1) (C\&S); Trinidad and Tobago; Trinidad, Río Matura. USNM 290406, (7); Trinidad and Tobago; Trinidad, Río Matura. H. jabonero: EBRG 4324, (20); Venezuela, Aragua; Río Limón Pozo 350m. from profauna, El Limón. EBRG 4324, (2) (C\&S); Venezuela, Aragua; Río Limón Pozo 350m from profauna, El Limón. IUQ 1450, (2) (C\&S); Venezuela, Aragua; Río Limón Pozo $350 \mathrm{~m}$ from profauna, El Limón. IUQ 533, (before MBUCV-V 24896), (3); Venezuela, Carabobo; Lake Valencia basin, Río El Ercigue, at North from San Joaquin. IUQ 554, (1); Río Orituco; Venezuela. IUQ 1189, (2); Venezuela; Río Rico at Western from Coro. IUQ 1188, (5); Venezuela, Carabobo; Río Tesorero, at Santa Rosa, 5 km from
Carabobo. H. jelskii: IUQ 1141, (2) (C\&S); Ecuador, Orellana; Río Divino to 1600 m.from pozo Chontayacu I, bloque 18 . H. metae: IAvH 3122, (10); Colombia, Casanare, Aguazul, Río Cachiza, Chichaca creek. H. orcesi: MEPN 001538, (17); Ecuador, Morona-Santiago; Río Tayusa, system Río Upano, Méndez-Sucua road. MEPN 001538, (4) (C\&S); Ecuador, Morona-Santiago; Río Tayusa, system Río Upano, road Mendez-Sucua. H. pautensis: IUQ 533 (Paratypes), (2) (C\&S); Ecuador, Morona-Santiago; Río Paute. H. polyodon: IUQ 1142 (before MEPN 001533), (2) (C\&S); Ecuador, Zamora; Antonio-Guadalupe creek. H. taeniurus: MHNLS 8046, (2); Venezuela, Monagas, Río Punceres, to $15 \mathrm{~km}$ of Quiriquire (635' N; 630' W). MHNLS 8070, (119); Venezuela, Río Monagas, Aragua (bridge on the Becerros Creek), Maturin-Quiriquire road, ca. $10 \mathrm{~km}$ Aragua-Maturin $\left(63^{\circ} 25^{\prime} \mathrm{W} ; 63^{\circ} 55^{\prime} \mathrm{N}\right)$ 100m.a.s.l. Bryconamericus tolimae: FMNH 56258 (paratypes), (4), Colombia, Ibagué. IUQ 484, (48), Colombia, Tolima, Ibagué, Pastales, $100 \mathrm{~m}$ before of Pastales Ibagué-Juntas road, Combeima, Magdalena system (4030'19" N; $75^{\circ} 17^{\prime} 46^{\prime \prime}$ W) $1586 \mathrm{~m}$.a.s.1.

\section{RESULTS}

Hemibrycon paez, new sp.

(Table 1 \& Fig. 1A, 3)

Holotype: IUQ 502, 40.2 mm LS; Colombia, Cauca, Inzá, Puerto Valencia, Upper Magdalena, La Topa creek, Río Paez, 100m ca. bridge at La Plata-Inzá road $\left(2^{\circ} 30^{\prime} 01^{\prime \prime} \mathrm{N}\right.$; 75॰58’06” W) 1175m.a.s.1., 30 Dec. 2002.

Paratypes: IUQ 503, (4) collected with holotype. MCNG 54099, (3) collected with holotype. IUQ 504, (3); Colombia, Huila, La Plata, El Retiro, Chontaduro creek, on the bridge at La Plata-La Argentina road $\left(2^{\circ} 18^{\prime} 51^{\prime}\right.$ " N; 7556’36” W) 1190m.a.s.1., 28 Dec. 2002. IUQ 505, (8); Colombia, Huila, La Plata, El Retiro, Chontaduro creek, Río La Plata $\left(2^{\circ} 18^{\prime} 17^{\prime \prime} \mathrm{N} ; 75^{\circ} 57^{\prime} 09^{\prime \prime} \mathrm{W}\right) 1205$ m.a.s.1., 29 Dec. 2002. IUQ 506, (1) (C\&S); Colombia; 

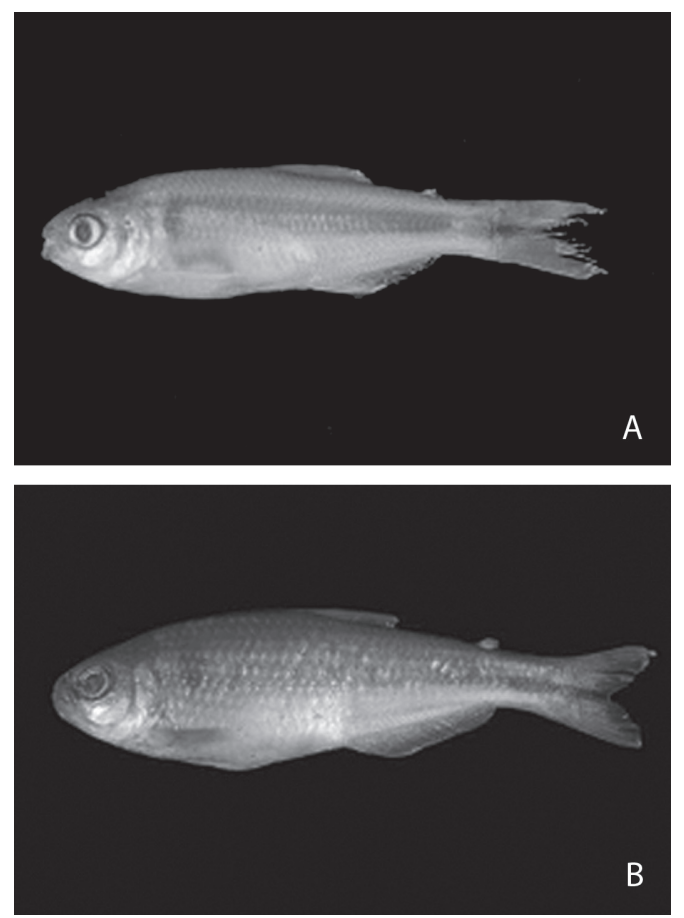

Fig. 1. A) Hemibrycon paez, Holotype. IUQ 502, 40.2mm LS; Colombia, Cauca, Inzá, Puerto Valencia, Upper Magdalena, La Topa creek, Río Paez; B) Hemibrycon quindos, Holotype. IUQ 485, 52.27mm LS; Colombia, Quindío, Salento, Upper Cauca, Río Quindío Basin, Tinaja creek $200 \mathrm{~m}$ at Llano Grande-Boquia road.

Huila, La Plata, Río La Plata, Mar. 1982. IUQ 507, (1) (C\&S); Colombia, Huila, La Plata, El Retiro, Chontaduro creek, Río La Plata $\left(2^{\circ} 18^{\prime} 17^{\prime \prime} \mathrm{N}\right.$; 7557'09” W) 1205m.a.s.1., 29 Dec. 2002. ICNMNH 1551, (6); Colombia; Huila, La Plata, Río La Plata, Mar. 1982. ICNMNH 1550, (1); Cauca, Inzá, Puerto Valencia, La Topa creek, Río Paez system, $100 \mathrm{~m}$ ca. at bridge at La Plata-Inzá road (2॰30'01" N; 7558'06" W) 1175m.a.s.l., Mar.1982. MTD F 2761727618, (2); Colombia, Huila, La Plata, El Retiro, Chontaduro creek, Río La Plata $\left(2^{\circ} 18^{\prime} 17^{\prime \prime} \mathrm{N}\right.$; 7557’09” W) 1205m.a.s.1., 29 Dec. 2002.

Diagnosis: Hemibrycon paez differs in number of lateral line scales ( 39 to 42 vs. 43 to 54; except 34 to 35 in $H$. orcesi), in the number of scales between lateral line and anal-fin
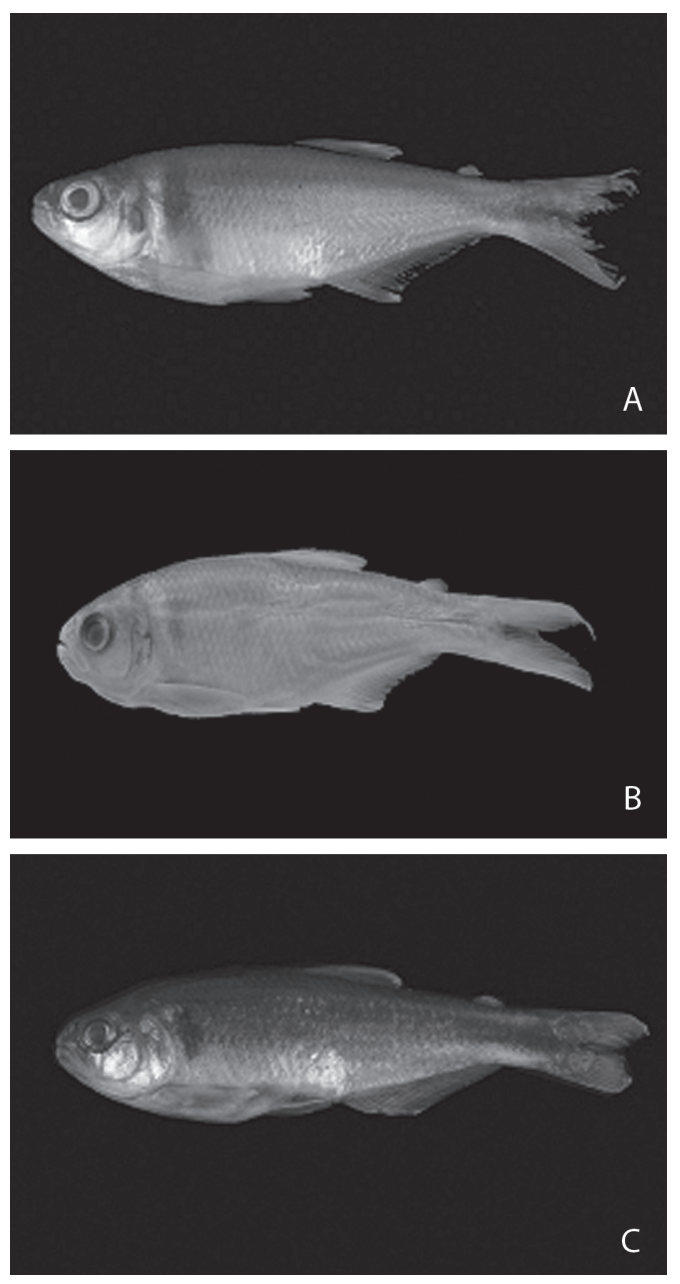

Fig. 2. A) Hemibrycon raqueliae, Holotype. IUQ 495, 88.88mm LS; Colombia, Caldas, Samaná, Middle Magdalena, Río La Miel Basin, Tasajo creek; B) Hemibrycon virolinica, Holotype. ICNMNH 6704, 59.05mm LS; Colombia, Santander, Virolín, Cañaverales creek on the Virolín-Sogamoso road; C) Hemibrycon yacopiae, Holotype. ICNMHN 6705, 59.15mm LS; Colombia, Cundinamarca, Yacopi, Hatico-Moral, Río Hatico, Río Aldana system, Middle Magdalena Basin, Oct. 1995.

origin (6 to 7 vs. 4 to 5 ; except 7 to 9 in $H$. colombianus) and scales between lateral line and dorsal-fin origin (6 to 7 vs. 8; except 7 to 10 in $H$. colombianus, $\mathrm{F}=53.47 \mathrm{n}=76 \mathrm{p}<1.27$ E-10). Additionally, most specimens of $H$. paez differ from those of $H$. boquiae, $H$. yacopiae and $H$. raqueliae in the number of anal-fin rays 


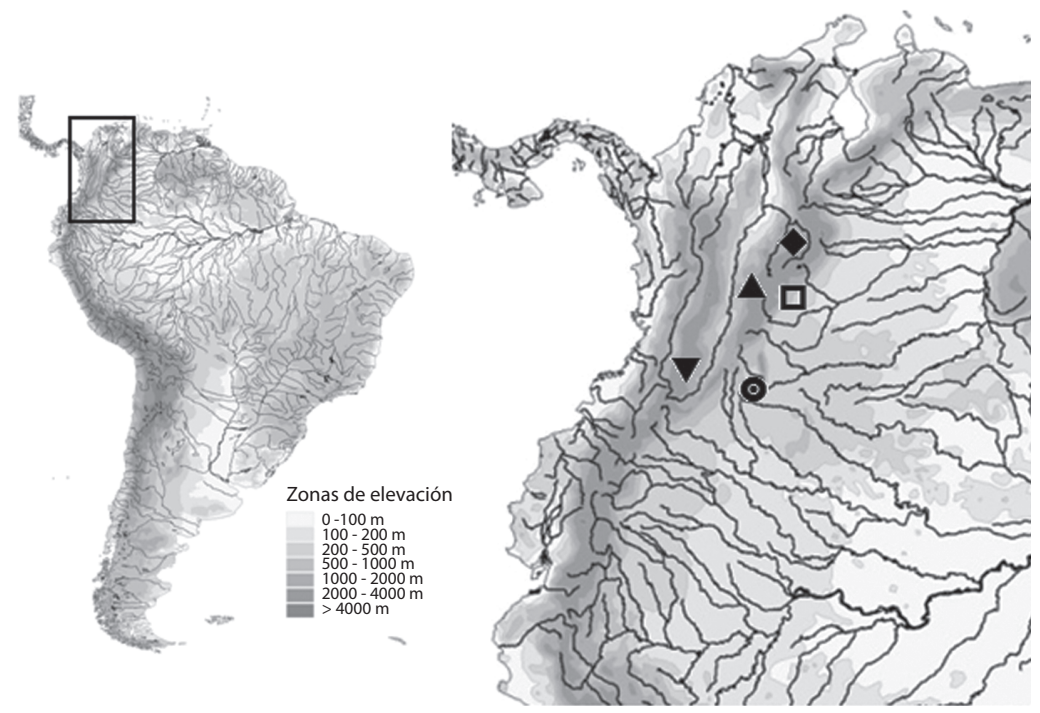

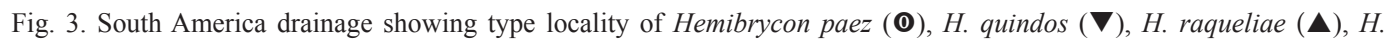
virolinica $(\bullet)$ and H. yacopiae $(\mathbf{\square})$.

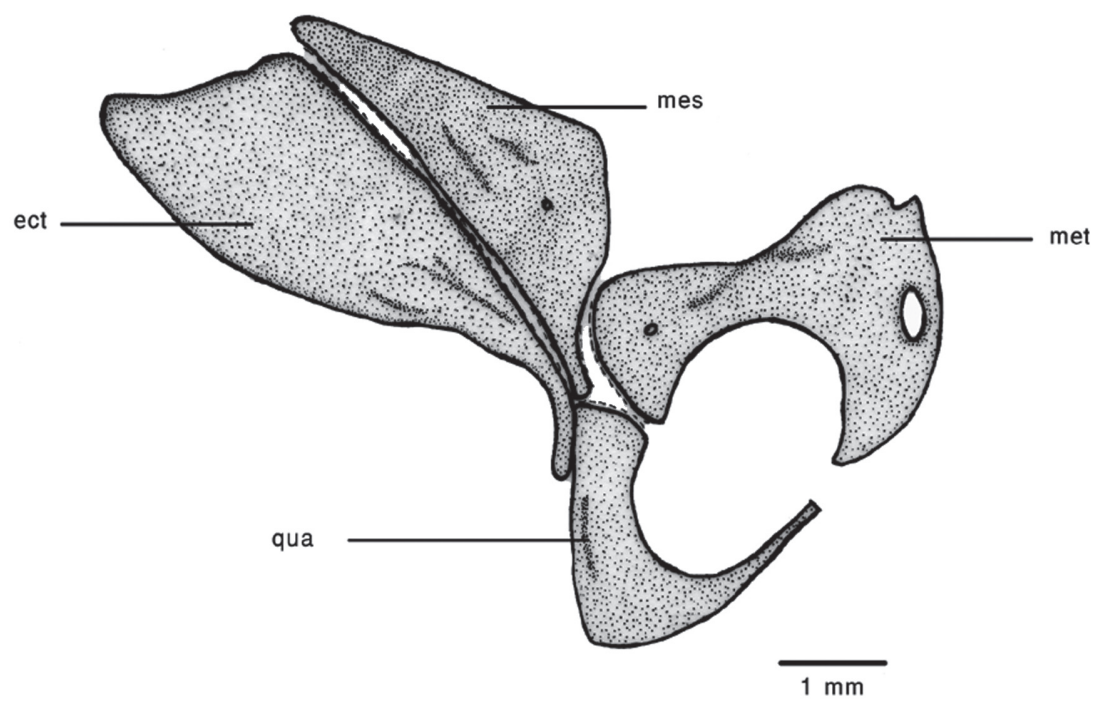

Fig. 4. Suspensorium of Hemibrycon paez. Cartilage is indicated by hatching.

(19 to 23 vs. 23 to 29 ). Too H. paez is readily distinguished from its congeners by having the mesopterygoid barely touching the metapterygoid (Fig. 4) (vs. overlapping the metapterygoid, except in $H$. jabonero, $H$. rafaelense and H. guppyi).
Description: Morphometric and meristic data for H. paez are presented in Table 1. Body elongate, dorsal profile of head oblique; area above orbits convex. Caudal peduncle laterally compressed in all specimens. Head and snout short; jaws equal, mouth terminal; lips 
soft and flexible, not covering external tooth row of premaxilla. Ventral border of upper jaw slightly concave. Maxilla ending posteriorly at vertical through of anterior border of orbit. Opening of posterior nostrils vertically ovoid; opening of anterior nostrils with posterior membranous flap.

Six infraorbitals bones present, all with laterosensory canal. Third infraorbitals long, wide, with ventral and posterior borders contacting preopercle. Supraorbital absent. Premaxilla with two rows of teeth. Outer tooth row with five-six tricuspid teeth arranged in straight line. Inner row with four tricuspid teeth, with central cusp slightly larger. Maxilla short with posterior tip not reaching vertical through anterior border of third infraorbitals. Maxilla with four to six teeth on the anterior and ventral borders. Specimens of $40 \mathrm{~mm}$ SL or smaller with four to ten tricuspid on maxilla, not extending a long entire anterior and ventral border. Dentary with three large teeth followed by nine unicuspid teeth. Dentary joined to angulo-articular through three apophyses.

Rhinosphenoid ossified. Orbitosphenoid with short, wide apophyses. Dorsal-fin margin oblique, second ray simple and first two branched rays longest. Mesopterygoid barely touching the metapterygoid. Pectoral girdle with sharp dorsal process on cleithrum, extending a long two-thirds of supracleithrum. Cleithrum short, located at level of posterior middle of opercle. Pelvic fin short, tip of fin almost reaching anal-fin origin. Pelvic bone elongated, straight, pointed, and running parallel to belly; ischiatic process short, with one small pointed apophyses.

Caudal fin forked with short lobes. Caudalfin rays 10/9. Pored lateral line scales 39-42, extending from supracleithrum to hypurals joint. Lateral line slightly curved ventrally between first and eighth or ninth scales, straight posteriorly. Total vertebrae 40-41.

Color in life: Dorsum green yellowish, lateral region silvery-blue and ventral region of the body silvery-white. Opercle spot present, silvery-yellow blotch present between opercular and humeral spot. Dark round humeral spot and round spot on caudal peduncle prolonged on to middle caudal ray fins present. Red spot present on the ventral posterior caudal peduncle. All fins hyaline, except caudal-fin lobes greenish-yellow.

Secondary sexual dimorphism: Males with reduced hooks on rays of anal, pelvic, pectoral and dorsal fins. A row of hooks on each branched pelvic-fin ray, which are distributed from the proximal end. All branched anal-fin rays with eight to 10 hooks along proximal end. Branched pectoral-fin rays with five to six hooks on the distal end. Branched dorsal-fin rays with five to six hooks on the distal end.

Distribution: This species is found in drainages of the Río La Plata, Upper Río Magdalena Basin.

Etymology: The name paez is a substantive noun in opposition, and refers to the native Latin Americans known as the Paeces or Guambianos who occupy the type locality of this new taxon.

Ecological notes: From the Río La Plata, La Topa and Chontaduro creeks: surface temperature $19.2-20.5^{\circ} \mathrm{C}$ (mean $19.7^{\circ} \mathrm{C}$ ), air temperature $18.8-22.8^{\circ} \mathrm{C}\left(\right.$ mean $\left.21.1^{\circ} \mathrm{C}\right)$, dissolved oxygen $7.6-8.0 \mathrm{mg} / 1$ (mean $7.9 \mathrm{mg} / \mathrm{l})$, saturation $98-100 \%$ (mean $99.2 \%$ ), clear water, width 5-6m, with substrate composed of stone, sand and decaying organic material.

\section{Hemibrycon quindos, new sp.} (Table 1 \& Fig. 1B, 3)

Holotype. IUQ 485 (male), 52.27mm LS; Colombia, Quindío, Salento, Upper Cauca, Río Quindío Basin, Tinaja creek $200 \mathrm{~m}$ at Llano Grande-Boquia road (4³6'57' N; 75³6'36" W) 1712m.a.s.1, 4 Dec. 2002.

Paratypes: Collected with holotype: IUQ 486, (18); IUQ 487, (28); Colombia, Quindío, Salento, Llano Grande, Upper Cauca, Río 
Quindío Basin, Tinaja creek $300 \mathrm{~m}$ at Llano Grande to Boquia road (4³6'57' N; 75³6'36" W) 1712m.a.s.1., 29 Jan. 2002. IUQ 488, (2) (C\&S); Colombia, Quindío, Salento, Upper Cauca, Río Quindío Basin, Tinaja creek, 300m at Llano Grande to Boquia road (4³6'57' N; 75³6’36” W) 1712m.a.s.l., 29 Jan. 2002. IUQ 489, (15); Colombia, Quindío, Salento, Upper Cauca, Río Quindío Basin, Tinaja creek, 300 $\mathrm{m}$ at Llano Grande to Boquia road (4³6'57' N; 75³6’36" O) 1712m.a.s.l., 11 Jul. 1996. MTD F 27621-27622, (2); Colombia, Quindío, Salento, Llano Grande, Upper Cauca, Río Quindío Basin, Tinaja creek, $300 \mathrm{~m}$ at Llano Grande to Boquia road (4³6' $57^{\prime \prime} \mathrm{N} ; 75^{\circ} 36^{\prime} 36^{\prime \prime}$ W) 1712m.a.s.1., 29 Jan. 2002.

Diagnosis: Hemibrycon quindos is readily distinguished from its congeners by one autopomorphic character (Arcila-Mesa 2008): Male with cartilaginous protuberance, rounded on all branched anal fin rays (vs. cartilaginous protuberance not present on anal-fin rays in males); by having the maxilla without a fold on its anterior end (vs. maxilla with folding only at posterior end, except in $H$. rafaelense). $H$. quindos differs in the number of pored scales in the lateral line ( 35 to 40 vs. 40 to 46 , $\mathrm{F}=118.1 \mathrm{n}=90 \mathrm{p}<2.03 \mathrm{E}-14$; except 46 to 54 in $H$. colombianus). $H$. quindos is similar to $H$. boquiae in having the depressed pectoral-fin falling short of the pelvic-fins origin and in its morphometric and meristic values; the species also differs in the form of the pelvic bone (blunt and osseous in the H. quindos, rounded and with cartilage in $H$. boquiae), form of orbitosphenoid (short and wide in $H$. quindos, slender and elongate in $H$. boquiae), and the number of small teeth on the dentary (ten in $H$. quindos, five in $H$. boquiae).

Description: Morphometric and meristic data for $H$. quindos are presented in Table 1. Body robust anteriorly, dorsal profile of head convex; area above orbits convex. Caudal peduncle laterally compressed in all specimens. Head and snout short; jaws equal, mouth terminal; lips soft and flexible, not covering external tooth row of premaxilla; ventral border of upper jaw slightly concave; maxilla ending posteriorly at vertical through anterior border of orbit, without a fold on its anterior end. Opening of posterior nostrils vertically ovoid; opening of anterior nostrils with posterior membranous flap.

Six infraorbitals bones, all with laterosensory canal. Third infraorbitals long, wide, with ventral and posterior borders in contact with propercle. Supraorbital absent. Premaxilla with two rows of teeth; outer row with four-five tricuspid teeth arranged in straight line. Inner row with four teeth with three or four cusps with central cusp slightly larger. Maxilla short with posterior tip falling short of anterior border of second infraorbitals. Maxilla with nine-ten tricuspid teeth, extending along anterior and ventral border. Dentary with three large teeth followed by ten small unicuspidate teeth.

Rhinosphenoid ossified. Orbitosphenoid with short, wide or narrow apophyses. Parasphenoid slender and undivided posteriorly. Without mesethmoid cartilage along dorsal and lateral margins, but with cartilage along anterior and dorsal margin of parasphenoid. Anterior portion of parasphenoid covering postero dorsal surface of vomer; posterior portion of parasphenoid in contact with prootic and basioccipital. Dorsal-fin margin oblique, second ray unbranched and first two branched rays longest.

Pectoral girdle with a sharp dorsal process on cleithrum, reaching one third of length of supracleithrum. Cleithrum long, located at level of posterior of middle portion of opercle. Pelvic fin elongate, tip of fin falling short of anal-fin origin. Pelvic bone elongated with tip straight and blunt. Ischiatic process short.

Caudal-fin unscaled, bifurcated with short lobes and pointed tips. Caudal-fin rays 10/11. Pored lateral-line scales 35-40, extending from supracleithrum to hypurals joint. Lateralline pores forming curve in ventral direction between the first and tenth scale with rest in straight line. Total vertebrae 39-40. 
Color in life: Dorsal greenish-yellow, lateral portion silvery-white (also blue-green or mulberry) the silvery-white color is more pronounced ventrally. Humeral spot dark and round. Round spot on caudal peduncle extending on to middle caudal-fin ray. Pectoral and pelvic fins yellow. Dorsal-fin hyaline; caudal fin reddish-yellow basally.

Secondary sexual dimorphism: Males with reduced hooks on rays of anal, pelvic, pectoral and dorsal fins. With a row of hooks on each branched pelvic-fin ray. All branched anal-fin rays with eight to ten hooks. Branched pectoral-fin rays with three to four hooks. Branched dorsal-fin rays with five to six hooks. All hooks on the distal end.

Distribution. This species known only from type locality.

Etymology. The name quindos is a substantive noun in opposition, and refers to the native Latin American people known as the Quindos, who once occupied the type locality of new taxon.

Ecological notes. See Román-Valencia $\&$ Botero (2006). Those authors also reported physical and chemical data of their habitat.

Hemibrycon raqueliae, new sp. (Table 2 \& Fig. 2A, 3)

Holotype: IUQ 495, 88.88 mm LS; Colombia, Caldas, Samaná, Middle Magdalena, Río

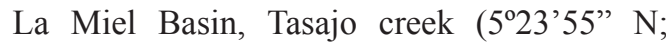
7459’05” W) 1482m.a.s.1., 3 Jan. 2003.

Paratypes: IUQ 496, (2); Colombia, Caldas, Samaná, Middle Magdalena, Río La Miel


W) 1482m.a.s.l., 3 January 2003. IUQ 497, (99); Colombia, Caldas, Samaná, La Vención, Middle Magdalena, Río La Miel Basin, Santa Rita creek, 4 Jan. 2003. MCNG 54102, (5); Colombia, Caldas, Samaná, La Vención, Middle Magdalena, Río La Miel Basin, Santa
Rita creek, 4 Jan. 2003. IUQ 498, (2) (C\&S); Colombia, Caldas, Samaná, La Vención, Middle Magdalena, Río La Miel Basin, Santa Rita creek, 4 Jan. 2003. ICNMHN 3281, (5); Colombia, Caldas, at Norcasia-Samaná road, Middle Magdalena, Río La Miel Basin, El Aquila creek; 8 Dec. 1992. MHNUC 019, (1); Colombia, Caldas, Manzanares, Middle Magdalena, Río Manzanares Basin (5'03'06" N; 75³5'05” W), 7 Dec. 1997. MTD F 2762527626, (2); Colombia, Caldas, Samaná, La Vención, Middle Magdalena, Río La Miel Basin, Santa Rita creek, 4 Jan. 2003.

Diagnosis: Hemibrycon raqueliae is distinguished from its congeners by having a widened first tooth on the maxilla with the remaining teeth decreasing sharply in size (Fig. 5) (vs. first tooth of maxilla slender, remaining teeth gradually diminishing), by having the first maxilla tooth pentacuspid and wider than the others (vs. first tooth on maxilla unicuspid or tricuspid and of same size as the others, except in $H$. colombianus and $H$. virolinica); by the absence of an expansion on the ventral anterior tip of the maxilla (vs. with expansion on the ventral anterior tip of the maxilla, except in $H$. metae). It differs from $H$. colombianus by the number of pored scales in the lateral line (42 to 46 vs. 46 to $54, \mathrm{~F}=398.4, \mathrm{n}=122 \mathrm{p}<1.24 \mathrm{E}-45$ ); and from the species of Hemibrycon from the Upper and Middle Río Magdalena drainage by the number of branched anal-fin rays (25 to 29 vs. 19 to $24, \mathrm{Q}=1.72 \mathrm{E}-05 \mathrm{p}<2.74 \mathrm{E}-39$ ).

Description: Morphometric and meristic data for $H$. raqueliae are presented in Table 2. Body robust anteriorly, dorsal profile of head oblique; area above orbits convex. Caudal peduncle laterally compressed. Head and snout short; jaws equal, mouth terminal. Lips soft, flexible, and not covering external tooth row of premaxilla. Ventral border of upper jaw slightly concave; maxilla ending posteriorly at vertical through anterior border of second infraorbitals. First tooth of maxilla pentacuspid, wider than rest which decrease sharply in size, ventral anterior tip of the maxilla not expanded. Opening of posterior nostrils vertically ovoid; 


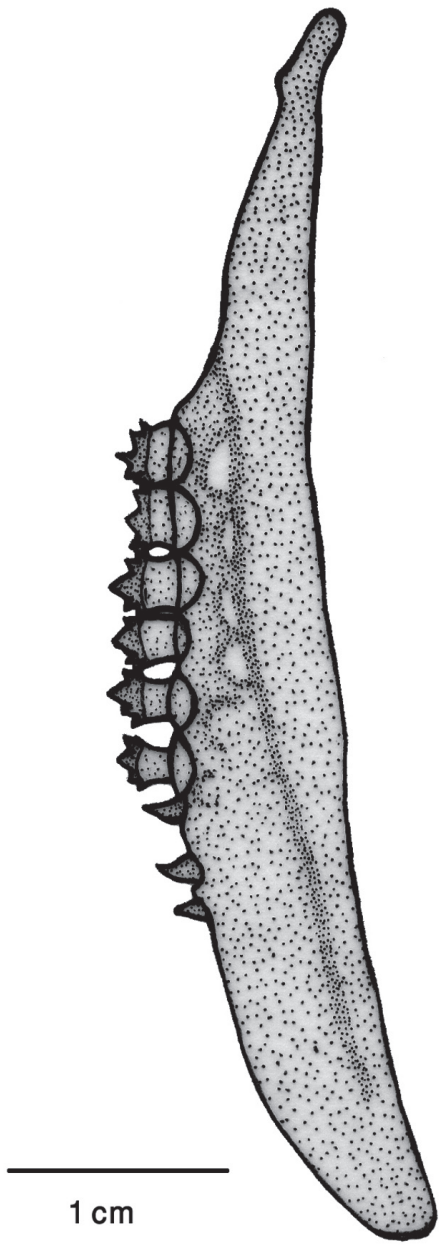

Fig. 5. Maxilla of Hemibrycon raqueliae.

opening of posterior nostrils with posterior membranous flap.

Six infraorbitals, all with laterosensory canal; third infraorbitals long, wide and with ventral and posterior borders in contact with preopercle. Supraorbital absent. Premaxilla with two rows of teeth. Outer tooth row with four or five pentacuspid teeth arranged irregular pattern. Inner tooth row with four tricuspid teeth, with central cusp larger. Maxilla short with posterior tip falling short of anterior border of third infraorbitals. Maxilla with six12 tricuspid teeth, and three unicuspid teeth, extending along anterior and ventral borders. Some immature specimens $(<50 \mathrm{~mm} \mathrm{SL})$ with only three to six teeth on maxilla, not covering all entire anterior and ventral borders. Dentary with three large pentacuspid teeth with central cusp largest, these teeth followed six to seven small teeth with one or three cusps.

Rhinosphenoid ossified. Orbitosphenoid with short, narrow apophyses. Parasphenoid elongate and undivided posteriorly. Mesethmoid cartilage lacking extension to dorsal and lateral margins of rhinosphenoid, but with cartilage along dorsal and anterior margin of parasphenoid. Dorsal-fin margin oblique, second ray unbranched and first two branched rays longest. Pectoral girdle with sharp dorsal process on cleithrum, extending $1 / 3$ length of supracleithrum. Cleithrum short, located at level of middle of length of opercle. Pelvic-fin elongate, with tip of fin not reaching anal-fin origin. Pelvic bone elongate with tips straight and blunt, with cartilage on postero-inferior end. Ischiatic process short, tip with two apophyses.

Caudal-fin unscaled, bifurcated with short lobes. Caudal-fin rays 10/9-10. Pored lateral line scales 42-46, extending from supracleithrum to hypurals joint. Lateral line pores forming slight curve in ventral direction between first and tenth scale with rest in straight line. Total vertebrae 42-43.

Color in life: Dorsal area dark blue, lateral region and ventral silvery white, more intense ventrally. Round humeral blotch dark gray. Orbit yellow dorsally. Round peduncle spot extending on to middle caudal ray-fins. A red spot present on ventral posterior caudal peduncle. All fin hyaline except anal fin which has dark rays and is hyaline basally.

Secondary sexual dimorphism: Males with row of hooks well developed on each ray segment of pelvic and anal-fins. Branched analfin rays with 3-13 hooks, on firth to twelfth rays. One simple pelvic-fin rays with three-11 
hooks; all branched pelvic-fin rays with 11 to 17 hooks on basal two thirds of rays.

Distribution: Río La Miel Basin, Middle Río Magdalena.

Etymology: The species is named to honor biologist Raquel Ivveth Ruiz Calderón, in recognition for her generous contribution of works for the preservation and study of Neotropical fishes.

Ecological notes: Surface temperature $21.5^{\circ} \mathrm{C}$, air temperature $22.4^{\circ} \mathrm{C}$, dissolved oxygen $7.0 \mathrm{mg} / \mathrm{l}$ and $60 \%$ saturation, width fivesix m. Substrate stone, sand, and decaying organic in decomposition and detritus, water crystalline.

Hemibrycon virolinica, new sp. (Table 2 \& Fig. 2B, 3)

Holotype: ICNMNH 6704, 59.05mm LS; Colombia, Santander, Charalá locality, Virolín creek, Río Cañaverales Basin, 27 April. 1983

Paratype: ICNMNH 2870, (5) collected with holotype. IUQ 501, (1) (C\&S) collected with holotype. ICNMHN 6736, (12); Colombia, Santander, Charalá locality, Virolín, Río Luisito-Río Virolín, La Cristala creek (606’24" N; 73¹1'55" W), 1759m.a.s.1., 29 Nov. 1978. IUQ 521, (9); Colombia, Santander, Charalá locality, Río Virolin, Río Cañaverales on the Virolin-Sogamoso road $\left(6^{\circ} 05^{\prime} 40^{\prime \prime}\right.$ N; 7311'58” W) 1744m.a.s.l., 4 Feb. 2004. MCNG 54103, (2); Colombia, Santander, Charalá locality, Virolín creek, Río Cañaverales on the Virolin-Sogamoso road $\left(6^{\circ} 05^{\prime} 40^{\prime \prime}\right.$ N; 73¹1'58” W) 1744m.a.s.1., 4 Feb. 2004. IUQ 522, (4); Colombia, Santander, Charala locality, Virolín creek on the Virolin-Sogamoso road (606’02" N; 73¹1'35" W) 1790m.a.s.1., 4 Feb. 2004.

Diagnosis: Hemibrycon virolinica is readily distinguished from its congeners by having the posterior end of the extrascapular spine surpassing the postemporal (Fig. 6) (vs. posterior end of extrascapular not exceeding postemporal



Fig. 6. Cranium of Hemibrycon virolinica.

spine); by having the posterior end of the first proximal pteryigiophores of dorsal fin of the same size as the anterior edge (vs. the posterior end of the first proximal pteryigiophores of dorsal fin more elongated than the anterior edge, except in $H$. polyodon). Additionally, $H$. virolinica differ from those of $H$. colombianus in the number of pored scales in the lateral line ( 40 to 44 vs. 46 to $54, F=145.3 n=70 p<3.20$ E-19); and from other species from the upper and middle Magdalena drainage by the absence of a lateral band and the presence of a pigmented adipose fin (vs. with lateral band and hyaline adipose fin).

Description: Morphometric and meristic data for $H$. virolinica are present in Table 2. Body robust, dorsal profile of head convex; area above orbits convex. Dorsal profile of body convex from supraoccipital to dorsal-fin origin posteroventrally, oblique from base of last dorsal-fin ray to caudal-fin base. Ventral profile of body convex from snout to analfin base, convexity more pronounced beyond 
posterior portion of pectoral-fin. Caudal peduncle laterally compressed. Head and snout short; jaws equal, mouth terminal; lips soft and flexible, not covering external tooth row of premaxilla. Ventral border of upper jaw slightly concave; maxilla ending posteriorly at vertical through of anterior border of orbit. Opening of posterior nostrils vertically ovoid; opening of anterior nostrils with posterior membranous flap. Six infraorbitals present, first five with laterosensory canal segment; third infraorbitals long, wide, with ventral and posterior borders in contact with preopercle.

Six infraorbitals present, all with laterosensory canal. Third infraorbitals long, wide, with ventral and posterior borders contacting preopercle. Supraorbital absent. Premaxilla with two rows of teeth. Outer tooth row with threefour tricuspid teeth arranged in straight line. Inner row with four tricuspid teeth, with central cusp larger. Maxilla short with posterior tip falling short of anterior border of third infraorbitals. Maxilla with six-ten tricuspid teeth, covering anterior and ventral borders of bone. Dentary with three or four large teeth followed by three small unicuspid teeth, located along posterior region.

Rhinosphenoid cartilaginous. Orbitosphenoid with large, narrow apophyses. Parasphenoid elongate and undivided posteriorly. Mesethmoid cartilage extending to anterior limit of parasphenoid. Anterior portion of parasphenoid cartilaginous, covering vomer; posterior portion of parasphenoid in contact with prootic and basioccipital. Nasal bones present. Dorsal-fin margin oblique, second ray unbranched and first two branched rays longest. The posterior end of the first proximal pteryigiophores of dorsal fin of the same size as the anterior edge. Pectoral girdle with sharp dorsal process on cleithrum, extending along $1 / 3$ of supracleithrum. Cleithrum long, located at level of middle of length of opercle. The posterior end of the extrascapular spine surpassing the postemporal. Pelvic-fin short, with tip of depressed fin falling short of anal-fin origin. Pelvic bone elongated, located parallel to belly, bone short, straight and sharp. Ischi- atic process short, convex, and with two pointed small apophyses.

Caudal-fin unscaled, bifurcated with short lobe ending in distinct point. Caudal-fin rays 10/9. Pored lateral line scales 40-44, extending from supracleithrum to hypurals joint. Lateral line pores forming slight curve in ventral direction between first and eighth scale with rest in straight line. Total vertebrae 39-41

Color in life: Dorsum dark, sides sliverywhite more so ventrally. Round violet spot on opercle. Dark humeral spot vertically elongate. A dark elongate band on caudal peduncle that extends on to middle caudal-fin rays. A red spot present on the ventral posterior caudal peduncle. Caudal-fin base dark yellow, lobes hyaline; pectoral fin yellow with rays dark basally, pelvic fins hyaline, dorsal fin with dark bands extending on to rays, more pronounced on the tips.

Secondary sexual dimorphism: Males with hooks developed on anal and pelvic fins rays. With 14 to 16 hooks on each branched pelvic-fin ray. First unbranched and next eight to nine branched of anal-fin rays with 10-11 hooks, all distributed at anterior ends of rays.

Distribution: This species is known only from the type locality.

Etymology: The species is named after the type locality, Virolín in Santander state Colombia.

Ecological notes: Water surface temperature $15.8-27.5^{\circ} \mathrm{C}$, air temperature $17.3-21.4^{\circ} \mathrm{C}$, dissolved oxygen $4.3-7.9 \mathrm{mg} / 1$ and $87-99 \%$ saturation, $\mathrm{pH}$ 6.9-8.1. Width 2-10m, substrate stone and sand, water coffee colored.

\section{Hemibrycon yacopiae, new sp. \\ (Table 2 \& Fig. 2C, 3)}

Holotype. ICNMHN 6705, 59.15mm LS; Colombia, Cundinamarca, Yacopi, HaticoMoral, Río Hatico, Río Aldana system, Middle Magdalena Basin, Oct. 1995. 
Paratype: ICNMHN 2390, (60) collected with holotype. IUQ 500, (2) (C\&S) collected with holotype. IUQ 515, (4); Colombia, Cundinamarca, Yacopi, Hatico-Moral, Río Hatico, Río Aldana system, Middle Río Magdalena Basin (5'31'22" N; 74¹9'30" W) 761m.a.s.1., 26 Aug. 2003. IUQ 516, (8); Colombia, Cundinamarca, Yacopi, La Mina creek at Yacopi-La Mina road, Río Magdalena Basin (5²5'51" N; 74¹9'59” W) 1094m.a.s.1., 27 Aug. 2003. MCNG 54104, (2); Colombia, Cundinamarca, Yacopi, La Mina creek at Yacopi-La Mina road, Río Magdalena Basin (5²5'51" N; 74¹9'59" W) 1094m.a.s.1., 27 Aug. 2003. MTD F 26627, (1); Colombia, Cundinamarca, Yacopi, La Mina creek at Yacopi-La Mina road, Middle Río Magdalena Basin (525'51" N; 74¹9'59" W) 1094m.a.s.l., 27 Aug. 2003.

Diagnosis: Hemibrycon yacopiae is readily distinguished from its congeners by the following autopomorphic characters (Arcila-Mesa 2008): first laterosensorial infraorbitals canal in contact with the posterior end of antorbital (Fig. 7) (vs. laterosensorial canal not reaching posterior end of antorbital); by having the tip of the supraoccipital spine widened (vs. supraoccipital spine acute), by the posterior end of ectopterygoid failing to come in contact with the quadrate bone (vs. in contact, with the exception of $H$. raqueliae); by the posterior



Fig. 7. Orbit region of Hemibrycon yacopiae. edge of palatine more widened than the anterior edge of ectopterygoid (vs. posterior edge of the palatine approximately the same size, except for $H$. paez). It differs from $H$. colombianus by the number of pored scales in the lateral line ( 40 to 42 vs. 46 to $54, F=359.7 n=112 p<9.83$ $\mathrm{E}-35)$ and the number of predorsal scales (10 to 14 vs. 14 to $18, F=217.2 \mathrm{n}=112 \mathrm{p}<1.04 \mathrm{E}-26$ ), and from the other species of upper and middle Magdalena drainage Hemibrycon by the number of scales between the lateral line and the pelvic fins ( 4 to 6 vs. $>6$ ).

Description: Morphometric and meristic data for H. yacopiae are presented in Table 2. Body elongate, dorsal profile of head oblique; area above orbit convex; dorsal profile of body posteroventrally oblique from supraoccipital to dorsal-fin origin, and from base of last dorsalfin ray to caudal-fin base. Ventral profile of body convex from snout to anal-fin base, convexity more pronounced beyond posterior portion of pectoral-fin. Caudal peduncle laterally compressed. Head and snout short; jaws equal, mouth terminal. Lips soft and flexible, not covering external tooth row of premaxilla. Ventral border of upper jaw slightly concave; maxilla ending posteriorly vertical through anterior border of orbit. Opening of posterior nostrils with posterior membranous flap.

Six infraorbitals, all with laterosensory canal segment. First laterosensorial infraorbitals canal in contact with the posterior end of antorbital. Third infraorbitals long, wide, with ventral and posterior borders in contact with preopercle. Supraorbital absent. Premaxilla with two rows of teeth. Outer row with four tricuspid teeth arranged in straight line. Inner row with four teeth with three or four cusps, with central cusp larger. Maxilla with posterior tip reaching posterior limit of second infraorbitals. Maxilla with seven to nine tricuspid teeth, covering anterior and ventral borders of bone. Immature specimens $(<50$ $\mathrm{mm}$ SL) with four to six teeth on maxilla, teeth extending along entire anterior ventral border. Dentary with three large tricuspid teeth with central cusp large, followed by 
eight small teeth, with one or three cusps. The tip of the supraoccipital spine widened. Rhinosphenoid ossified. Orbitosphenoid short and blunt. Parasphenoid elongate and undivided. Mesethmoid cartilage contacting dorsal and lateral margins of rhinosphenoid and extending to anterior limit of parasphenoid. Anterior portion of parasphenoid cartilaginous and covering posterodorsal surface of vomer; posterior portion of parasphenoid in contact with prootic and basioccipital. The posterior end of ectopterygoid failing to come in contact with the quadrate bone; the posterior edge of palatine more widened than the anterior edge of ectopterygoid. Nasal bones present. Dorsalfin margin oblique, second unbranched ray and first two branched rays longest. Pectoral girdle with sharp dorsal process on cleithrum, extending $1 / 3$ of length of supracleithrum. Cleithrum short, located at level of middle of length of opercle. Pelvic fin elongate, with tip of fin falling short of anal-fin origin. Pelvic bone located parallel to belly; pelvic bone short, straight and sharp; ischiatic process short, straight, and with two pointed apophyses posteriorly.

Caudal-fin unscaled, bifurcated with short and pointed lobes. Caudal-fin rays 10/9. Pored lateral line scale 40-42, extending from supracleithrum to hypurals join. Lateral line pores forming slight curve in ventral direction between first and fourth scale with rest in straight line. Total vertebrae 40-41.

Color in life: Dorsal region dark yellow, lateral region silvery-white, more so ventrally. A round violet spot present on opercle. Humeral spot dark and vertically elongate. Elongate dark peduncle spot prolonged on to middle caudal ray-fins. Specimens from Río Hatico with dorsal portion of caudal-fin yellow-white to dark yellow, rest of fins hyaline. Specimens from La Mina creek with pectoral and pelvic-fins hyaline, dorsal-fin with dark spot on rays, more so dorsally. Adipose fin red. Caudal-fin base greenish- yellow with hyaline tips. Anal-fin hyaline basally dark gray or yellowish-green. Pectoral fin hyaline. A red spot is present on the ventral posterior caudal peduncle.
Secondary sexual dimorphism: Males with reduced hooks on each branched rays of anal, pelvic, pectoral and dorsal fins. With a row of hooks at each branched ray of pelvic fins. All branched anal-fin rays with eight to nine hooks. Branched of pectoral fin with five to six hooks. Branched dorsal-fin rays with four to five hooks all are distributed near the distal end.

Distribution: This species known only of type locality.

Etymology: The species is named after the type locality, Yacopi, Cundinamarca state in Colombia.

Ecological notes: Surface water temperature $20.1-24.6^{\circ} \mathrm{C}$, air temperature $20.7-26.5^{\circ} \mathrm{C}$, dissolved oxygen $5.0-7.4 \mathrm{mg} / \mathrm{l}$ and $69-96 \%$ saturation, $\mathrm{pH}$ 7.3-7.6, width two-three $\mathrm{m}$. Substrate stone and sand. Water color dark grey to crystalline.

\section{DISCUSSION}

The morphological diversity of Hemibrycon species from the Río Magdalena basin has led to recognition of many new Hemibrycon species. Hemibrycon, Bryconamericus and Astyanax, have long been considered problematic genera due to the absence of characters to differentiate species. Dahl (1971) recognized this situation regarding Hemibrycon species of the Río Magdalena system. The presence of cartilaginous protuberance on the anal-fin rays is an autoapomorphy for Hemibrycon quindos (Arcila-Mesa 2008). This character state has only rarely been observed in other characid fish: Bryconamericus cascajalensis, species of the genus Myxiops, two species of Monotocheirodon and undescribed species of Othonocheirodus (Zanata \& Akama 2004, Weitzman et al. 2005). The histological examination of these structures reveals that they consist of accumulations of epithelial cells (Wiley \& Collette 1970, Zanata \& Akama 2004). These epidermal structures have been considered variable and in 
some cases, only present in males or at certain stages of ontogenetic development (Zanata \& Akama 2004, Weitzman et al. 2005).

The logistic regression model for the presence of protuberance on anal-fin rays of $H$. quindos had a prediction percentage of $26.44 \%$ and $19.68 \%$, when adjusted $\left(\mathrm{r}^{2}=0.0105059\right.$ Length Standard X Sex +16.0538$)$. Sex is correlated to the presence of cartilaginous protuberance (0.0004), unlike body length, which was not significantly correlated with protuberance presence (0.1442). The probability of cartilaginous protuberance on the of anal fin rays of males is much higher than for females $\left(9.37708 E^{6}\right)$. In males the protuberance are present in both young fish as well as adults, and in a few were also observed on caudal-fin rays. Their location is variable on the anal-fin rays. This coincides with what was observed for the species Myxiops (Zanata \& Akama 2004).

The presence of hooks on the rays of all fins (except caudal fin) has been recorded in other species Hemibrycon: $H$. divisorensis, $H$. rafaelense, $H$. boquiae, $H$. brevispini and $H$. cairoense (Bertaco et al. 2007, Román-Valencia \& Arcila-Mesa 2008, Román-Valencia et al. 2009). In $H$. raqueliae and $H$. virolinica hooks are present only on the rays of the anal and pelvic fins. The presence of hooks on the rays of all fins has been considered an uncommon character state for characid species as was discussed by Bertaco et al. (2007) and Román-Valencia et al. (2009a). The Hemibrycon species described in this paper, present an allopatric distribution (Fig. 3). This distribution model is associated with the geological history of the Río Magdalena system, strongly influenced by catastrophic tectonic events, which have led to isolation and separation of drainages and played a decisive role in the model of vicariant speciation. That is an explanation for the distribution of Hemibrycon quindos, $H$. virolinica and $H$. yacopiae, each restricted to a single drainage, while $H$. paez and $H$. raqueliae were characterized by populations from more than one drainage. The drainages were characterized by oligotrophic conditions, with high dissolved oxygen, which indicate the importance of conserving these Neotropical ecosystems with a high degree of endemism.

\section{ACKNOWLEDGMENTS}

The Fundación para la Promoción de la Investigación y la Tecnología del Banco de la República of Colombia and University of Quindío, Vicerrectoría de Investigaciones (grants 212 and 304) financed the study; IDEA WILD provided field equipment. We further thank Raquel I. Ruiz-C. (IUQ), Axel Zarske (MTD F) and two anonymous reviewers for excellent suggestions and corrections. We also thanks the following persons and museums for loans of material under their care: Francisco Provenzano and Alberto Mercano (MBUCV), Ramiro Barriga (MEPN), Francisco Bisbal and Rafael Suarez (EBRG), Carlos Lasso and Oscar-Lasso Alcalá (MHNLS), Barry Chernoff and Mary Anne Rogers (FMNH), Yaneth Muñoz-S (ICNMNH), W.N. Eschmeyer and Jon Fong (CAS), José E. Castillo and Fabio Quevedo A. (IAvH), Jesús Vélez (Museo de Historia Natural, Univ. de Caldas, Manizales, Colombia), Richard P. Vari and Lisa Palmer (USNM). Alejandro Escobar Ruiz (London) prepared figures 1 and $2(\mathrm{~A}, \mathrm{~B}$ and $\mathrm{C}$ respectively).

\section{RESUMEN}

Cinco nuevas especies son descritas para la cuenca del Río Magdalena, Colombia, con base en caracteres morfométricos, merísticos y osteológicos. Hemibrycon paez se distingue por el número de escamas en la línea lateral ( 39 a 42 vs. 43 a 54), entre la línea lateral y el origen de la aleta anal (6 a 7 vs. 4 a 5), y entre la línea lateral y el origen de la aleta dorsal (6 a 7 vs. 8). H. quindos se distingue por una autopomorfia: machos con protuberancias cartilaginosas redondeadas sobre los radios ramificados de la aleta anal, sobre toda su extensión (vs. no presentes en los radios de las aletas anal en machos), la maxila que no posee un plegamiento en su extremo posterior (vs. maxilar con doblamiento en su extremo posterior), por el número de escamas con poros en la línea lateral (35 a 40 vs. 40 a 46). $H$. raqueliae, se distingue por presentar el primer diente del maxilar ensanchado al comparar con los demás dientes que disminuye abruptamente en tamaño (vs. primer diente del maxilar delgado, los demás dientes disminuyen gradualmente), por presentar el primer diente de la maxila 
pentacúspide y más ancho que los demás (vs. primer diente sobre la maxila uni o tricúspide y de igual tamaño que los otros. $H$. virolinica se distingue por poseer en el extremo posterior del extraescapular una espina que sobre pasa el postemporal (vs. extremo posterior del extrascapular no sobre pasa la espina del postemporal), por tener el extremo posterior del primer pterigióforo proximal de la aleta dorsal del mismo tamaño que el borde anterior (vs. el extremo posterior del primer pterigióforo proximal de la aleta dorsal mas alargado que el borde anterior). H. yacopiae se diferencia por una autopomorfia: el canal laterosensorial sobre primer infraorbital en contacto con el extremo posterior del antorbital (vs. el canal laterosensorial no alcanza el extremo posterior del antorbital), por el extremo de la espina supraoccipital ancha (vs. espina supraoccipital aguda), por el extremo posterior del ectopterigoide no en contacto con el cuadrado (vs. en contacto), por el borde posterior del palatino más ancho que el borde anterior del ectopterigoide (vs. borde posterior del palatino aproximadamente del mismo tamaño).

Palabras clave: Hemibrycon, teleostei, nuevo taxón, pez neotropical.

\section{REFERENCES}

Arcila-Mesa, D.K. 2008. Análisis filogenético y biogeográfico de las especies del género Hemibrycon (Characiformes, Characidae). Tesis de grado B. Sc. Programa de Biología, Universidad del Quindío. Armenia, Colombia.

Bertaco, V.A., L.R. Malabarba, M. Hidalgo \& H. Ortega. 2007. A new species of Hemibrycon (Teleostei: Characiformes: Characidae) from the río Ucayali drainage, Sierra del Divisor, Peru. Neotrop. Ichthyol. 5: $251-257$.

Dahl, G. 1971. Los peces del norte de Colombia. Inderena, Bogotá, Colombia.

Eschmeyer, N.W. 2005. CAS-Ichthyology-catalog of fishes. California Academy of Sciences. San Francisco, USA.

Eigenmann, C. H. 1927. The American Characidae. Mem. Mus. Comp. Zool. 43: 311-428.

Géry, J. 1962. Notes on the ichthyology of Surinam and other Guiana. The distribution pattern of the genus Hemibrycon, with a description of a new species from Surinam and an incursion in to ecotaxonomy. Bull. Aquatic Biol. 3: 65-80.

Lima, F.C.T., L. R. Malabarba, P. A. Buckup, J. F. Pezzi da Silva, R. P. Vari, A. Harold, R. Benine, O. T. Oyakawa, C.S. Pavanelli, N.A. Menezes, C.A.S.
Lucena, M.C.S. Malabarba, Z.M.S. Lucena, R.E. Reis, F. Langeani, L. Cassati, V.A. Bertaco, C. Moreira \& P.H. Lucinda. 2003. Genera Incertae Sedis in Characidae. p. 106-169. In: Reis, R.E., S.O. Kullander \& C.J. Ferraris (eds). Checklist of the freshwater fishes of South and Central America. EDIPUCRS. Porto Alegre, Brazil.

Planquette P., P. Keith \& P. Le Bail. 1996. Atlas des Poisson d'eau douce de Guyane. Tome I, Muséum National d'Histoire Naturelle. Paris, France.

Román-Valencia, C. 2001. Redescripción de Hemibrycon boquiae (Pisces: Characidae), especie endémica de la quebrada Boquia, cuenca Río Quindío, Alto Cauca, Colombia. Dahlia (Rev. Asoc. Colomb. Ictiól.) 4: 27-32.

Román-Valencia, C. 2004. Redescripción de Bryconamericus tolimae (Pisces: Characidae), especie endémica del Río Combeima, cuenca Río Magdalena, Colombia. Dahlia (Rev. Asoc. Colomb. Ictiól.) 7: 23-27.

Román-Valencia, C. \& A. Botero. 2006. Trophic and reproductive ecology of a species of Hemibrycon (Pisces: Characidae) in Tinajas Creek, Rio Quindio drainage, upper Cauca basin, Colombia. Rev. Mus. Argentino Cienc. Nat., n.s. 8: 1-8.

Román-Valencia, C., R.I. Ruiz-C \& R. Barriga. 2006. Una nueva especie de pez del género Hemibrycon (Characiformes: Characidae). Rev. Biol. Trop. 54: 209-217.

Román-Valencia, C., R.I. Ruiz-C \& R. Barriga. 2007. Redescripción de Hemibrycon orcesi Böhlke 1958 y H. polyodon (Günther 1864) (Teleostei: Characidae), incluye clave para las especies de Hemibrycon en Ecuador. Anim. Biodivers. Conserv. 30: 179-187.

Román-Valencia, C. \& D.K. Arcila-Mesa. 2008. Hemibrycon rafaelense $\mathrm{n}$. sp. (Characiformes: Characidae), a new species from the upper Rio Cauca, with keys to Colombian species. Anim. Biodivers. Conserv. 31.1: 67-75.

Román-Valencia, C., R.I. Ruiz-C \& A. Giraldo. 2008. Dieta y reproducción de dos especies sintónicas: Hemibrycon boquiae y Bryconamericus caucanus (Pisces: Characidae) en la quebrada Boquia, río Quindío, Alto Cauca, Colombia. Rev. Mus. Argentino Cienc. Nat. n.s. 10: 55-62.

Román-Valencia, C. \& D.K. Arcila-Mesa. 2009. Two new species of Hemibrycon (Characiformes: Characidae) from the Magdalena river, Colombia. Anim. Biodivers. Conserv. 32.2: 77-87. 
Román-Valencia, C., D.K. Arcila-Mesa \& H. Hurtado. 2009a. Variación morfológica de los peces Hemibrycon boquiae y Hemibrycon rafaelense (Characiformes: Characidae) en el río Cauca. Rev. Biol. Trop. 57:541-546.

Roman-Valencia,C., R.I. Ruiz-C. \& D.C. Taphorn. 2009b. Hemibrycon santamartae a new species from the Rancheria River of Eastern Caribbean Colombia (Characiformes:Characidae). Revista de Investigaciones, Univ. Quindio 19: 1-8.

Román-Valencia, C., C.A. Garcia-Alzate, R.I. Ruiz-C. \& D.C. Taphorn. Submitt. A new Hemibrycon: $H$. barreroi n. sp. from Güejar River, Orinoco Basin, Colombia. Vert. Zool.

Taylor, W.R. \& G.C. Van Dyke. 1985. Revised procedures for staining and clearing small fishes and other vertebrates for bone and cartilage study. Cybium 9: 107-119.

Vari, P.R. 1995. The Neotropical fish family Ctenolucidae (Teleostei: Ostariophysi: Characiformes) supra and intrafamilial phylogenetic relationships, with a revisionary study. Smith. Contr. Zool. 564: 1-96.
Vari, P.R. \& D.J. Siebert. 1990. A new, unusually sexually dimorphic species of Bryconamericus (Pisces: Ostariophysi: Characidae) from the Peruvian Amazon. Proc. Biol. Soc. Wash. 103: 516-524.

Weitzman, S.H. 1962. The osteology of Brycon meeki, a generalized characid fish, with an osteological definition of the family. Stanford Ichthyol. Bull. 8: $1-50$

Weitzman, S.H., N.A. Menezes, H.G. Evers \& J.R. Burns. 2005. Putative relationships among inseminating and externally fertilizing characids, with a description of a new genus and species of Brazilian inseminating fish bearing an anal-fin gland in males (Characiformes: Characidae). Neotrop. Ichthyol. 3: 329-360.

Wiley, M.L. \& B.B. Collette. 1970. Breeding protuberance and contact organs in fishes: their occurrence, structure, and significance. Bull. Amer. Mus. Nat. Hist. 3: $143-216$.

Zanata, A.M. \& A. Akama. 2004. Myxiops aphos, new characid genus and species (Characiformes: Characidae) from the rio Lençóis, Bahia, Brazil. Neotrop. Ichthyol. 2: 45-54. 